\title{
The Flipped Classroom: High School Student Engagement Through 21st Century Learning
}

Kent F. G. Avery and Carolyn T. Huggan, Department of Education, Prince Edward Island

\author{
Jane P. Preston, University of Prince Edward Island
}

\section{Authors' Note}

The authors extend sincere appreciation to the Joint Educational Research Group, Faculty of Education, University of Prince Edward Island for funding this research.

\begin{abstract}
The purpose of this qualitative study is to document the experiences of students who participated in a flipped classroom during a Grade 11 Modern World History and a Grade 11 Biology course. An abridged literature review revealed the flipped classroom provides enriched opportunities for collaborative learning and for greater teacher-student interaction; however, during the homework phase, some students are not equipped to be independent learners. For this action research project, we collected data from 48 students who completed three sets of qualitative questionnaires and participated in two focus groups. Augmented data included excerpts from reflective journals maintained by the flipped classroom teachers. From the data, three dominant themes surfaced. First, the flipped classroom promoted active learning. Second, it supported stronger relationships among students and their teachers. Third, it activated a steep learning curve. Details of 21st century learning are used to conceptualize the findings. One implication of the study is that, at the start of the flipped experience, teachers need to communicate fluidly to students what the flipped classroom is and is not.
\end{abstract}

Keywords: flipped classroom; action research; 21st century learning 


\section{The Flipped Classroom: High School Student Engagement Through 21st Century Learning}

Until about the 1900s, world knowledge doubled every century; shortly after World War II, world knowledge doubled about every 25 years (Schilling, 2013). These days, world information is doubling every one to two years. In the future, as the internet and technology become exceedingly more powerful, influential, and ubiquitous, knowledge is expected to double every 12 hours (IBM, 2006). Life in this information-rich future will be distinctly different. By 2030, robots are expected to replace 800 million jobs (BBC News, 2017). The next generation will likely own self-driving cars and experience nanotechnology embedded in their bodies. The near future probably includes trips to the moon and the establishment of colonies on Mars.

To address these societal shifts and the breakneck speeds of these changes, educational institutions need to assume new teaching and learning styles that align with 21 st century ways of thinking, acting, and being (Gardner, 2008; Pink, 2005). As a part of this transformation, teachers are changing the way students interact with curriculum. A style of pedagogy that serves the needs of the modern student is the flipped classroom. In describing its salient principles, the flipped classroom is a method of delivering curricular content via pre-class videos, which are viewed as homework (Fultan, 2014). Then, with knowledge of that topic, students enter the classroom ready to critically analyze the content through open discussions, pair-share activities, student presentations, quizzes, and mini-lessons, for example (Rotellar \& Cains, 2016). Using Bloom's taxonomy of learning, watching the instructional video reflects lower levels of cogitative learning (i.e., knowledge and comprehension), and class-time interrogation of the content reflects higher forms of learning (i.e., application, analysis, synthesis, and evaluation).

The flipped classroom is an example of pedagogy that aligns with a 21 st century style of learning. Although there are various definitions associated with 21 st century learning, herein, we define the concept as developing core competencies such as collaboration, communication, critical thinking, character/self-confidence, and creativity, which are dominant skills students need to possess to survive and thrive personally and professionally in the modern, future world. The details and nuances of a 21st century style of learning are articulated by figureheads such as Howard Gardner (2008) and Daniel Pink (2005) and by organizations such the Partnership for 21st Century Skills (2016) and Canadians for 21st Century Learning and Innovation (Milton, 2015). These academics and associations assert that to meet current and future societal needs (including the labor force requirements of the modern globalized economy), educational institutions must undergo vast restructuring (Kereluik, Mishra, Fahnoe, \& Terry, 2013). School and educators must demote a 20th century, knowledge-based style of literacy, which was of value for the industrial age, and replace it with 21 st century learning, where students master content by producing, synthesizing, and evaluating information from a variety of sources, while simultaneously assuming an understanding of and respect for global cultures and worldviews (Milton, 2015).

Focusing on this new style of learning, the purpose of this study was to document the experiences of students who participated in a flipped classroom in a Grade 11 Modern World History and a Grade 11 Biology course. Kent Avery taught the social studies course, and Carolyn Huggan taught the science course, both of whom are co-authors and co-researchers of this action research project. For this qualitative study, data were collected via three sources. First, 48 (of a possible 54) students completed open-ended questionnaires at the beginning, middle, and end of their respective flipped classroom course. These 48 students also partook in two focus groups, 
and both teachers maintained a personal journal during the course. Reference to 21 st century teaching and learning ideologies are highlighted in the discussion of the results.

For many reasons, this research is timely, practical, and significant. First, the study was conducted in the Canadian province of Prince Edward Island (PEI). Within this province, Preston et al. (2015) found many educators who incorporated technology into their teaching were using basic digital tools like YouTube, multimedia presentations (e.g., PowerPoint, Prezi, etc.), and class websites. Despite the general need for teachers to integrate more technology into education, research shows that growth in this area is slow, challenging, and somewhat superficial (Abbitt, 2011; Bauer \& Kenton, 2005). Second, according to Abeysekera and Dawson (2015), research on the flipped classroom is "under-evaluated, under-theorised and under-researched" (para. 4). Third, within the literature, we found almost no Canadian peer-reviewed research pertaining to the flipped classroom for elementary or secondary schools. The vast majority of flipped classroom research was conducted in non-Canadian, postsecondary environments, accentuating the need for this study. Finally, this study was conducted through an action research design (Efron \& Ravid, 2013; Mertler, 2017; Noffke \& Somehk, 2011), which, among other things, means the findings are relevant to the researchers, themselves, and, reflecting on the study's findings helps the teacher researchers adjust their instruction to better address student needs (Mertler, 2017).

\section{Literature Review}

As mentioned, contextualized research about the flipped classroom in high school is limited; however, such a focus in postsecondary environments is well documented (see Honeycutt, 2016; Reidsema, Kavanagh, Hadgraph, \& Smith, 2017; Talbert, 2017; Waldrop \& Bowdon, 2016). The available research spotlights many benefits of the flipped classroom. First, in postsecondary settings, much research shows that the use of the flipped classroom improves student engagement, student motivation, student attitude toward learning, and the quality of teacherstudent interactions (Arnold-Garza, 2014; Clintondale High School, 2012; Donovan \& Lee, 2015; Enfield, 2013; Gross, Pietri, Anderson, Moyano-Camihort, \& Graham, 2015; McLaughlin et al., 2013; Rotellar \& Cains, 2016). Second, some studies reveal that students who are assigned video lectures for homework, as compared to textbook readings, are better prepared upon entering the classroom (de Grazia, Falconer, Nicodemus, \& Medlin; Gross et al., 2015; Mok, 2014). Third, with the flipped classroom, students can re-watch, rewind, and/or fast-forward the videos. In other words, students can manipulate the pace in which they receive content (Abeysekera \& Dawson, 2015; Arnold-Garza, 2014; Enfield, 2013); therein, they can assume high levels of ownership and responsibility for their own learning (Educause, 2012; Mok, 2014; Laman, Brannon, \& Mena, 2012). Fourth, flipped pedagogy provides teachers with class time to interact with individual students, formatively assess students, and recognize the potential learning gaps of students (Bergmann \& Sams, 2012; Fultan, 2014; Kovach, 2014). Fifth, because the videos are accessible, documented lessons, the videos are a resource that can be given to students when they are absent from class (Enfield, 2013). In summarizing these benefits, the flipped classroom provides enriched opportunities for self-directed, collaborative learning, while allowing for greater teacher-student interaction, all of which are important components of $21 \mathrm{st}$ century learning experiences.

However, not all the research on the flipped classroom is constructive. According to Tang et al. (2017), flipped learning can place a great burden upon the student during the homework 
phase, and some students may not be equipped to be independent learners of new subject matter. Aggravating this issue, students who do not watch the videos come to class unprepared to participate in activities that are based on the video information (Herreid \& Schiller, 2013). Research shows that for the students who enjoy the freedom of asking questions in class during lectures, the flipped classroom was less enjoyable and less interactive (Khanova, McLaughlin, Rhoney, Roth, \& Harris, 2015). Nielsen (2012) emphasized that, with the educational movement toward no homework policies, flipped learning might not be an ideal fit for some public schools. In addition, the creation of the videos may be challenging, because instructors may need to learn new technological and pedagogical skills to create them (Educause, 2012). Finally, high quality videos that are content-laden, concise, and pedagogically sound take a lot of time to prepare (Arnold-Garza, 2014; Enfield, 2013; Khanova et al., 2015; Tolks et al., 2016). In summarizing this information, challenges associated with the flipped classroom are similar to the challenges of traditional lecture-style pedagogy. In both scenarios, students are faced with assuming responsibility for their own learning, and the teacher is faced with time-consuming professional development issues surrounding content preparation.

\section{Research Methodology and Design: Qualitative Action Research}

At its core, the qualitative paradigm is about understanding human experiences (Marshall \& Rossman, 2011; Merriam, 2009; Patton, 2015). For this research, we used a qualitative methodology, because the study documented the experiences of high school students and the flipped classroom. In further clarifying its organizational dimensions, this study assumed an action research design (Efron \& Ravid, 2013; Mertler, 2017; Noffke \& Somehk, 2011). Mills (2017) explained:

[Action research] is inquiry research conducted by teachers, administrators, counselors, and others with a vested interest in the teaching and learning process or environment for the purpose of gathering information about how their particular schools operate, how they teach and how their students learn. (p. 5)

It is a form of research that bridges the gap between theory and practice (aka praxis), and it is commonly used by teachers who want to improve their pedagogical practices (Efron \& Ravid, 2013 Mills, 2017). Action research is often described as a cyclical process (Drummond \& Themessl-Huber, 2007; Mills, 2017). This cycle is described in various ways by different authors, but it usually involves four phases: planning, acting, observing, and reflecting/implementation phases. For this research, the planning phase involved three researchers-two public high school teachers (Kent and Carolyn) and one university faculty member (Jane). By participating in the research, collecting student data, and maintaining a personal journal (i.e., the acting phase), it was the intent of the teacher researchers to observe and understand the learning needs and experiences of the students. The end of the research involved a deep reflection about the study and, accordingly, the teacher researchers adapted their pedagogy to improve student learning for future classes. For these teachers, action research served as a type of hands-on professional development to further develop their effectiveness in leading a flipped classroom.

\section{Data Collection and Analysis}

Kent's Grade 11 Modern History course had 25 students; Carolyn's Grade 11 Biology course had 29 students. Before agreeing to participate in the study, students and their parent/guardians 
were given invitation/information letters about the research. After both the student and his/her parent/guardian understood the details of the study, to be a participant in the study, each student signed a consent form. Of the possible 54 students enrolled in both courses, 48 students signed the consent form, thus, agreeing to participate in the research.

Data were collected via three sources: student questionnaires, student focus group interviews, and a daily journal maintained by instructors. First, students completed three anonymous open-ended questionnaires. The first questionnaire was distributed three weeks after courses began, and 42 of 48 students completed this questionnaire. The second questionnaire was distributed seven weeks into the course, and all 48 students completed that questionnaire. The last questionnaire was completed at the end of five-month course. Again, all 48 students completed it. Each questionnaire contained three questions, which asked students to document such things as their learning preferences, new skills they acquired due to the flipped class, challenges they experienced due to the flipped class, and the overall impact flipped learning had on them.

After completion of the courses, 48 students partook in two focus groups. The first focus group was held in the school theater, where all 48 students from both courses gathered. Projected on a screen, a list of guiding questions led the large group discussion, ${ }^{1}$ which lasted 59 minutes. During the large focus groups, 15 of the 48 students chose to orally articulate their views, opinions, and beliefs about the flipped classroom. A second, smaller focus group with six student volunteers was conducted. This interview lasted 84 minutes. These six students were also present during the large-group discussion, but, in reviewing the transcripts, only one of these six students spoke during the large group discussion. In total, of the 48 students who partook in the study, 20 students orally articulated their experiences and thoughts during focus group discussions. Both focus groups were audio-recorded, and transcripts were created from the recordings. Due to limited space, the predominant data reported here is from the questionnaires and focus groups; however, a few journal excerpts from the instructors are also included.

Data were formally analyzed through content analysis (Savin-Baden \& Major, 2013), which was enacted through stages. First, the reflective journal documented the researchers' initial interpretation of data (Ortlipp, 2015; Phelps, 2005). This journal echoed the instructors' opinions, thoughts, and feelings about student experiences and about their own pedagogical considerations while teaching a flipped course. Second, we assembled typewritten questionnaire answers, focus groups transcripts, and typewritten reflective journals. The researchers read and reread these data several times to gain familiarity with the overall content. Third, the questionnaire answers, focus group transcripts, and journal excerpts were reread but more systematically to create categories of key ideas, phrases, commonalities, differences, and patterns (Marshall \& Rossman, 2011; Merriam, 2009). At this stage, similar categorical themes were merged into larger themes in response to the research purpose (Miles, Huberman, \& Saldaña, 2014). With the research purpose at the forefront of our minds (i.e., what were the experiences of students who participated in a flipped classroom while enrolled in Grade 11 Modern World History or Grade 11 Biology?), we reread the questionnaire answers, focus group transcripts, and journal excerpts again. From this analysis, three dominant themes surfaced. The flipped classroom promoted active-learning, supported learner relationships, and stimulated a steep learning curve. Under each of these major themes, reoccurring sub-themes evolved, which are outlined below. 


\section{Findings}

For the findings, we include student quotations and paraphrased data, which are poignant and representative of the thematic results. The use of quotation promotes credibility of findings, gives participants voice, and enhances readability (Anderson, 2010). The use of paraphrased data provides a succinct way to articulate participant opinions and thoughts. With the exception of the instructors (i.e., Kent and Carolyn), all names used are pseudonyms for the students who participated in focus groups. When incorporating questionnaire data, no name is provided, because questionnaire answers were anonymous.

\section{Active-Learning}

Independence. Many students explained that the flipped classroom required that they assume more responsibility for their own learning, especially outside of the classroom. Lucas talked about this external classroom experience:

You actually have to be an adult. You have to self-teach yourself. You have to watch stuff at home. You have to do your work. You need to stay on top to make sure you continuously grow as a student.

Jackson said, "The flip classroom has helped me learn on my own." James stipulated, "[The flipped classroom] makes me become a more independent person, and I don't have to rely on a teacher to help me along the way." Kennedy made somewhat of the same point when she said, "It helped me become more responsible as a student and take charge of my own learning." Mia believed, through watching the homework videos, she was learning to learn and said, "I've grown a lot academically, because I've learned how to study better on my own." Oliver believed the flipped classroom made students responsible for their own learning and saw it as a "sink or swim" type of learning. Toward the end of the course, as Kent reflected on the students learning, he wrote, "Applying oneself in the flipped classroom is paramount. If you are unprepared to do the work and find greater meaning and purpose in your own learning, then this course has been difficult."

A statement on questionnaire was, "What skills have you potentially gained from the flipped style of learning?" Like focus group responses, many questionnaire answers showed that students believed the at-home aspect of the flipped classroom forced them to be independent learners. For example, concerning what the flipped classroom was about, students said:

- " $\quad$ taking greater responsibility for my own learning."

- "Independence-[it] enhanced how I study and learn on my own."

- " "It has made me more of an independent learner."

- " "It has helped me to learn for myself."

One student pointed out, "I don't believe this [the flipped class] is for high school, though. It should be for university as my marks have suffered as a result of it." Overall, students explained that watching the homework videos made them more responsible for their own learning, a process that a couple students labelled as "adult learning."

Accessibility and convenience. Students explained that being a self-directed learner involves having course content accessible, having the teacher accessible, and being in control of one's learning. Mason was very appreciative of the availability of online notes, which 
accompanied some of the videos. He explained that he often forgot his binder at school, and, for him, it was convenient to be able to access notes on his phone. Carter also referred to this convenience when he said, "It's a lot easier to carry around a phone in your pocket than it is to carry around a book or notes." Several students made the point that, "There's more things going on in [my life] than school" (Sadie). Students explained they had busy lives. For example, many students participated in sports, volunteered in the community, and/or assumed part-time jobs. Sadie thought that reviewing videos and notes for homework was a style of learning that suited her well, because she enjoyed learning in the comfort of her home on her own time, especially because she had such a busy life. In sum, many students viewed the delivery and dynamics of the flipped classroom as a convenient, comfortable, and accessible way to learn.

Engaged. As part of a questionnaire, we asked these high school students to identify their favorite ways to learn. Their answers included such things as discussions, debates, hands-on labs, and experiential learning. Then many students went on to explain that the flipped classroom provided a time and a space to do such activities. Zoe stated, "An advantage of the flip classroom is we could have these large discussions." Nora said, "Advantages of it [the flip classroom] are all the group conversations." Several students were excited by the technological addition of the videos. Sadie was excited by the homework and said, "Videos are more exciting, like there's something different that you can experience." Ryan's comment was similar: "To touch on the videos again, I think they might even be a more valuable teaching asset than just notes ... they kind of immerse you more."

During the face-to-face portion of the flipped class, Anna explained that she was motivated to orally express her views. Carter welcomed the unique classroom learning environment of the flipped class. He explained:

When you do the same thing from Kindergarten to Grade 11, it's just the same thing all the time. So it's [the flipped class] a change of atmosphere, and it's more engaging because you're not ... bored as much with the same old routine.

Jackson compared his non-flipped classes to the flipped class:

Some teachers, when I go to their classes, I know exactly what's going to happen. I'm going to go in. They're going to say hi or whatever. We're going to talk for five minutes. They're going to do some notes and give us a sheet. But when you come to the flipped classroom, it's a different thing every day.

Many focus group comments indicated that students were often bored in classes; in contrast, the flipped classroom made room for exciting, novel ways to learn.

On the questionnaire, we asked students to explain how the flipped environment potentially affected student participation during class. The content of most answers showed that they were more engaged and interested in class. Specific answers were:

- "I am more engaged and asked more questions. I discovered how to think before I speak about an issue."

- "The flipped classroom has made things more interesting."

- "I have become more involved in the class as a result of the flipped classroom."

- "It has been engaging because it is a more active way of learning."

- " $[\mathrm{I} \mathrm{am}]$ interested in discussions." 
- "I have become more involved and invested in class."

- "Class is never boring."

As undertone to these answers, many students were excited to participate in, what they viewed as, a new approach to learning. However, there were a few students who did not enjoy aspects of the flipped class. Some of these comments were: "I have lost interest in this course as a result of the flipped classroom," and "Learning has become more difficult- $[\mathrm{I}$ 'm] drowning in a mountain of work."

Carolyn and Kent's journal excerpts also provided information related to student engagement. At the beginning of class, Carolyn and Kent checked to see if student completed the flipped homework. They noticed that when students watched the homework videos (and reviewed the notes when applicable), the students were engaged in class.

Empowered: Learning and life skills. Students identified the skills they believed they acquired due to the flipped learning experience. Main answers included visual learning skills, questioning skills, critical thinking skills, debating skills, listening skills, socialization skills, attentiveness, open-mindedness, and the ability to use a different worldview to critically reflect. Several students said the self-directed learning experience was akin to gaining the life skills they needed in order to be successful in other courses and in adulthood. Ryan described a type of epiphany he had shortly after experiencing flipped learning. He said, "It just kind of dawned on you that you have to go home and take initiative and be more responsible with your work and put more effort into it if you wanted to succeed." Brendan believed the flipped class helped him think critically. He said, "Instead of just learning facts, we got to actually dig deeper and see the other side of things." Oliver stated, "The flipped class is really good to prepare you for postsecondary education, because it really teaches you to be more independent. You're the only one driving yourself." Adding to Oliver's comment, Lucas stated, "The flipped classroom is just preparing you for university and life in general to do your own work and save your own butt. So if you're going to slack in this, you're not going to go far." Organizational skills and time management were learning proficiencies that many students believed they acquired due to the flipped classroom experience. For these students, the dynamics of the flipped classroom required that they be organized. Jackson explained how the flipped classroom helped him overcome procrastination. He said:

For me, I'm a pretty lazy kid. Like, when I go home, some days, I won't take my books knowing that I have homework. That's just kind of who I was I guess. And like, the flip classroom you have to do the work, or you're not going to pass, you know what I mean?

On the questionnaire, one student stated, "I have developed the ability to not leave stuff to the last minute," and another said, "I feel more organized."

Although most students felt proud of their learning, a few students saw little to no difference in their learning or in the learning attitudes of peers. One student said, "I feel lost and frustrated not knowing the material, but I have no time to look at notes at home," and another said, "More independence for learning allowed me to slack off." Carter talked about his friends' passiveness when he said, "My friends wanted it [learning] to be more like paint-by-numbers sort of thing. They didn't want to apply themselves. They just wanted to have the answers given to them." Many students identified that a lack of personal effort was the root of a stagnant learning. 
Through the flipped classroom, the instructors attempted to promote engagement via critical thought during classroom activities. However, early in the course, the instructors observed that some students were struggling with this type of analysis. For example, after the first two weeks, Carolyn wrote, "We have encountered our next hurdle_critical thinking skills." She explained that many students are used to being given the answers. She continued, "Others who have these skills need immediate feedback to know their answers are correct. Hopefully the flipped classroom will help instill confidence and critical learning skills to help students be lifelong learners." Then, two months into the course, Kent explained, "I had a brief encounter with two students in the hall today ... Both students talked about the fact that our class is less about memorization and more about critical analysis, and they liked that."

\section{Stronger Relationships}

Teacher-Student. Carolyn and Kent's journals reflected greater opportunities for individual assessment of students. The in-class activities allowed the teachers the freedom to observe students, identify the successes and needs of students, therein, strengthening their learner relationship with students. For example, a month into the research, Kent observed, "I am very impressed with [name of student] ... Although she is not vocal with the whole group, her ability to take the prior learning and use it in assignments, quizzes, and tests is very astute."

Students believed the videos strengthen teacher-student relationships. Part of the reason for these stronger relationships was because the instructors taped the videos in various locations, such as in their home and within the local community. Seeing the teacher in contexts other than in the school helped Carter identify with his teacher in a new way. On this topic, he said:

You see him [Mr. Avery] at his house doing a video for us. It's more of a ... person in general, not just a teacher who you have at school ... that more human, one-on-one type of interaction, relationship type of thing, rather than just being a teacher.

Hailey also spoke of the different type of learning connection she experienced with her teacher due to the videos. She said, "You do get to see a lot more of Mr. Avery and that also helps with, like, asking questions. ... whenever you can relate to a teacher more, it's easier to ask them questions." Hailey believed that the video interactions fostered more trust in her teacher, because she realized her teacher was a real person outside of the school environment. Reviewing questionnaire answers, several students explained that they felt more comfortable asking teachers questions, because they regularly saw their teachers in the videos. Some students concluded that, if a teacher employs a flipped method of teaching, these teachers need to be active learners, themselves. Carter explained, "The fact that both sides are learning, the teacher and the students, it helps, because they can sort of relate to us more." These data show that the flipped class appeared to change some of the power dynamics associated with traditional learning; the teacher went from being viewed as somewhat of a serious, authoritarian, inaccessible figure to being seen as an approachable person open to addressing student questions, while simultaneously learning in the process.

Another aspect of the flipped environment that affected the teacher-student dynamics was technological communication. Ryan believed teachers who flip their class need to be technologically available, and, "if you want to ask any particular question, you could just send the teacher a message" (Ryan). "Any teacher who tends to do the flip classroom, tends to be 
more available or ready to answer you" (Carter). Regularly seeing their teachers on videos made some students less intimidated to email questions. Sadie explained:

The only teacher I ever emailed ... was my flipped classroom teacher ... she was real easy to reach out to. She was always available and wanting to interact with her students, even if that meant when she was not in the classroom.

Sadie believed that the flipped dynamics of the classroom made these teachers more open to digital submissions of work. On this note, she explained, "Also, the flipped classroom teachers, like Mrs. Huggan and Mr. Avery, they're the only two teachers-where I've been in a classwhere you can hand things in online.

Student collaboration. Many students recognized that, because they were given the content to review for homework, their class time was dedicated to collaborative forms of learning. As Kent said, "There is a learning community developing here and students feel much more at ease to share their opinions and ideas about history." Many questionnaire comments pertained to aspects of this collaborative learning and the influence it had on them:

- "It helped me to become more responsive during class time."

- "This class has helped me feel greater comfort in speaking and expressing myself in classrooms."

- "[There is] more time in class to discuss topics."

- "I can talk about what we discussed in class at home."

- "It has taught me to actively think about the context and consider ideas."

- " $[\mathrm{I} \mathrm{am}]$ interacting with my own opinion by talking with peers in class discussions"

- "I am better at working with others."

- "I broke out of my shell to speak."

About a month into the course Kent wrote, "[Name of student] and [name of student] obviously have viewed the material outside of class and are compensating for the others who have not. They are now teaching and reviewing with the others in the class." These comments highlight that the collaborative peer discussions students experienced not only nurtured greater dialogue between students, it promoted critical thought about the content being learned.

\section{Learning Curve}

Skepticism, misconception, and adjustment. At the beginning of the courses, many students were dubious about the flipped classroom. Scarlett said, "At the beginning of the semester, I think everyone was really, kind of, nervous ... not a lot of people knew what it was about. [We] thought we were going to fail the course." James explained, "I was skeptical about the flipped classroom at first." Hailey described what her friends said about the flipped classroom when they initially experienced it:

I would hear other people around me say like, "Oh my God, I hate the flipped classroom. It's stupid."... It was only a week in, but they'd be like, "Oh I don't like this, and how are you supposed to do this and this?" ... I think some of us were probably like that because we're not use to it, right?

Liam's first impression of the flipped class was not positive, either: 
When I was introduced to the flip classroom, I was like, "Oh, this is going to be stupid. This is not going to change class whatsoever." [But] whenever we actually started getting into ... things, like doing debates instead of tests and stuff, it actually helped out quite a bit, and I thought it isn't as stupid as I thought it'd be.

Mason confessed he "was a little scared" upon hearing that his Biology course was going to be flipped, and Zoe's initial remark was, "Oh, dear!" after she heard her Modern History course was going to be flipped. Jackson provided an interesting comment about a flipped classroom misconception. "When I heard about the flipped classroom, the first thing that came to my mind was 'no homework,' and I was like, 'sweet, that's unreal.' Honestly, for like a month, I did nothing, and I watched my mark go down." About two weeks into the course, Kent described the student homework situation:

Some students are not prepared for class, which is not all that different from a traditional classroom. This is troublesome though in a flipped classroom, because it doesn't allow those unprepared students to delve deeper into a theme or subject material.

At the beginning of the courses, it appeared that the students misunderstood their responsibilities associated with the flipped classroom and/or miscalculated the importance of watching the videos.

Most students spoke about the adjustment phase they experienced. One said, "[It was] difficult to adapt to [the flipped class]," and another said, "Learning how to use technology as part of my own learning [was challenging]." Carolyn explained that it took about three weeks before her students adapted to and began to accept this new study of learning. She wrote, "There is an increase in the number of students who are coming to class prepared with a hard copy of the notes in their binders and/or demonstrating knowledge of reading the material prior to class."

For Carolyn and Kent's flipped classroom, the homework video was often accompanied with online notes. As mentioned above, many students liked the provision and accessibility of these notes; moreover, though, the online accessibility of notes opened up class time for other learning. Charlotte said, 'I find that, since the notes are online, and we don't have to write them down in class, we have a lot more time to do class discussions and things, which is how I learn best." James liked the online notes and the time they freed up during class, which then was filled with student-focused, participatory activities. One student said, "[I] like not copying notes in class," and another said, "More time in class for other things is a good thing rather than taking notes."

Although many students liked receiving notes online, some students preferred taking notes during class, because, through note-taking, they made meaning of the content. Mason explained, "For me, I like to learn more when we're in a classroom and get the notes there, because then I'm allowed to ask questions." Some questionnaire comments included, "I miss not taking notes during class," and "I feel lost and frustrated not knowing the material. I have no time to look at notes at home." Two weeks and four weeks into the course, Carolyn described the note-taking preferences of two particular students. "[Name of student] mentioned that he would understand the material better if I let them copy notes in class," and "[Name of student] has come to realize that he benefits from copying down notes (quote, 'Helps me learn'). He has made a home adjustment where he recopies his notes." As a side point, these quotes reflect 
metacognitive skills of some students who recognized that they preferred lecture-style, in-class, note-taking rather than receiving online notes.

Student advice. When asking students for advice for instructors who are considering the flipped class, students were vociferous. Lucas succinctly stated, "You have to warn them [the students]" ahead of time. Anna said, "Help them [the students] ease into it, and don't like push it on them too strongly. Just realize that it might take a little bit for them to get used to it and understand it." Kennedy said that the instructor needed to accentuate, at the start of class, that the students need to keep up with the course workload. Similarly, a questionnaire comment was that it was important for the teachers to clearly explain to students that completing the homework was vital to in-class learning. Mason thought it would be a good idea for him and his classmates to write a letter to future students describing what they need to do to be successful in a flipped class.

Students talked about the grade-appropriateness of the flipped classroom. Ryan thought the flipped experience should start in high school, because, at that time, it is important to "change learning attitudes of students." Other students thought it should be implemented before Grade 11. Jackson suggested it be introduced in Grade 9, after which all high school courses should be flipped. Sadie thought the first six years of elementary school should not be flipped, but then students should experience "another six years of the flipped classroom." One student concluded, "This is happening too late in public school-need this to be introduced earlier."

\section{Summary and Discussion of Results}

Summarizing the results of this research, the flipped classroom helped most student become confident, active learners. This learning success was dependent on whether student could or did assume responsibility for their own independent learning and whether they watched the homework videos. Many students viewed flipped learning as a convenient, comfortable way to learn. They believed the flipped experience supplied them with new skills, which they believed were needed for postsecondary education and for success as an adult. By watching and listening to their teachers on videos that were taped in various locations outside the school, they recognized their teachers as accessible, approachable, and more than just a classroom teacher. They viewed their teacher as a learner, too; thereafter, trust began to pervade some teacherstudent interactions. During class, student began to critically analyze curricular content; however, instructor journals highlighted that some students were at the beginning stages of development in this area. At the start of the flipped classroom, most students were skeptical of the experience and believed flipped learning would be easy and would be accompanied by a light workload. A few weeks into the course, many students realized they needed to put forth more effort and do their homework. Student had advice for teachers who might consider using the flipped class. Teachers should ensure that, before starting a flipped class, students have a full understanding of what flipped learning is. Teachers need to clearly articulate the student responsibilities associated with flipped learning.

Under the auspices of 21 st century learning, there is a veritable disjuncture between how education was delivered and perceived in past centuries as compared to the current one. Unable to compete with modern accessible information (e.g., cell phones, iPads, tablets, laptops, netbooks, etc.), teachers are no longer the dominate holders of knowledge. Instead, they are the facilitators of student learning (Action Canada Taskforce, 2013), a point reinforced through this 
research. Through homework videos and associated notes, teachers facilitated or provided learning opportunities, but students needed to assume responsibility for their own learning. During the initial stages of the flipped experience, there was notable student resistance to this new style of learning. Some students described the flipped classroom as isolated learning, because they thought watching the homework videos meant they had to learn new content on their own. The flipped classroom was somewhat of a shock to many students, especially when they realized the work associated with independent learning and the personal responsibility they needed to assume for certain components of the flipped class. However, many students realized that during the independent learning phase of the flipped classroom, the teacher could be reached. A key aspect of the student's successful independent learning was that the teacher needed to be accessible, approachable, and trustworthy. Interestingly, technology appeared to complement these traits. Regularly seeing the teachers on videos, which were taped in various locations, took the teacher out of the class. Through an asynchronous video, the teacher appeared to be less judgmental and more supportive. Also, when students recognized that their teachers were using the flipped classroom for the first time; they appreciated that their teacher was learning new skills, too. As leaders of their first flipped classroom, Kent and Carolyn were learners, risk-takers, and collaborators, similar skills they asked of their students. These flipped classroom instructors were non-intimidating role models of 21 st century learning.

For Kent and Carolyn, the flipped classroom was about releasing their dominance in front of the class and embracing a collaborative student-centered community of synergetic, symbiotic classroom learners. The $21 \mathrm{st}$ century teacher-student dynamic reinforces learning to be decentralized, non-hierarchical, social, hyperlinked, collaborative, and synergetic (Preston, Jakubiec, Jones, \& Earl, 2015), and it encourages students to be knowledge activators, producers, and disseminators (Fullan, 2013, 2014; Prensky, 2012; November, 2010, 2012). Twenty-first century learning calls for each student to be a tutor, coach, and instructor for his/her classmates, and, at times, the student needs to be a teacher of their teacher (especially in the dynamics of action research). Instructor journals documented how students, during class, were sometimes called upon to be a learning support for peers. For this study, the flipped experience called upon the student to collaborate and communicate with each other in the classroom during discussions, for example. Perhaps this valuable student collaboration could be extended through the provision of online student homework guides or leads, who could be of assistance for students who found the videos difficult to understand on their own. The flipped classroom also required students to be critical thinkers during class activities involving as content analysis. Skills associated critical analysis also appeared to be difficult for some students, especially at the beginning of the course.

Implications for this action research are grounded in the authors' contemplation of how they could have improved their instruction for flipped learning. First, to address the steep learning curve documented by the students in this study, teachers who employ the flipped classroom need to communicate clearly to the students what the flipped class is and is not. For example, flipped learning is not, as some students originally thought, free class time. Second, teachers thinking about using a flipped class for the first time might start with a pilot or trial flipped class where they teach a curriculum unit, instead of the entire course. In such a manner, both the teacher and student can gain experience and confidence in how to effectively teach and learn via flipped pedagogy. Third, teachers could ask former students who experienced the flipped classroom to explain to novice students the do's and don'ts of flipped learning. In 
addition, schools might organize elective flipped class courses, where students volunteer for the flipped learning experience.

\section{Concluding Remarks}

The flipped model of learning is a way to infuse 21 st century learning into public education. Changes in student demographics, the world economy, and global immigration, and advances in technologies have made the school environment much different than it was a mere decade ago. The delivery of education in public schools is at innovative crossroads, and new forms of pedagogy, as reflected in this research, need to be employed if teachers are to supply students with the learning experiences they need for their future success and wellbeing. Although techniques and philosophies that focus on student-centered learning have existed for decades, the flipped classroom is a contemporary approach that can be used to partially address the needs of 21st century learners (Rotellar \& Cains, 2016).

We end by reflecting on the words of Milman (2012) who indicated, "Although there are many limitations to the flipped classroom ... instructors maintain that it can be used as a valuable strategy at any level, depending on one's learners, resources, and time" (p. 86). Indeed, teachers can and should consider employing the flipped classroom if they wish to enhance student learning, improve student outcomes, and fully equip students to address 21 st century needs. However, we advise teachers that if they want to promote enhanced student learning via the flipped classroom, they need to do more than just move from physically giving a traditional lecture in front of the class to providing that same lecture in video format. Teachers contemplating the flipped classroom need to reflect on such things as technological resources, professional development needs, out-of-school email accessibility to students, and to plan student-focused pedagogy during class. The flipped pedagogy is an intertwined process of students becoming both autonomous and cooperative learners, who are immersed in relationshipdependent learning. Under these considerations, teachers can more effectively strategized and implement a successful flipped classroom.

\section{Endnote}

${ }^{1}$ This large focus group was a mode of data collection, but it also served as a metacognitive learning activity for the students. In other words, the focus group discussion was a class activity directed at helping students reflect upon and understand their own learning preferences. 


\section{References}

Abbitt, J. T. (2011). An investigation of the relationship between self-efficacy beliefs about technology integration and technological pedagogical content knowledge (TPACK) among preservice teachers. Journal of Digital Learning in Teacher Education, 27(4), 134-143.

Abeysekera, L., \& Dawson, P. (2015). Motivation and cognition load in the flipped classroom: Definition, rationale and a call for research. Higher Education Research \& Development, 34(1). Retrieved from http://www.tandfonline.com/doi/full/10.1080/07294360.2014.934336

Action Canada Task Force. (2013). Future tense: Adapting Canadian education systems for the 21 st century. Retrieved from http://www.actioncanada.ca/wpcontent/uploads/2014/04/TF2-Report_Future-Tense_EN.pdf

Anderson, C. (2010). Presenting and evaluating qualitative research. American Journal of Pharmaceutical Education, 74(8), 141-152.

Arnold-Garza, S. (2014). The flipped classroom teaching model and its use for information. Communications in Information Literacy, 8(1), 7-22.

Bauer, J., \& Kenton, J. (2005). Toward technology integration in the schools: Why it isn't happening. Journal of Technology and Teacher Education, 13(4), 519-546.

BBC News. (2017, November 29). Robot automation will 'take 800 million jobs by 2030_ report. Retrieved from http://www.bbc.com/news/world-us-canada-42170100

Bergmann, J., \& Sams, A. (2012). Flip your classroom: Reach every student in every class every day in. Washington, DC: International Society for Technology in Education.

Clintondale High School. (2012). Flipped school model of instruction. Retrieved from http://www.flippedhighschool.com/

de Grazia, J. L., Falconer, J. L., Nicodemus, G., \& Medlin, W. (2012, Jun). Incorporating screencasts into chemical engineering courses. The American Society for Engineering Education (ASEE) Annual Conference \& Exposition, San Antonia, TX. Abstract retrieved from https://peer.asee.org/incorporating-screencasts-into-chemical-engineeringcourses-2012

Donovan, J. D., \& Lee, S.-Y. (2015). How we flipped: Student and instructor reflections of a flipped-class model in a sensory evaluation laboratory course. NACTA Journal, 59(4), $335-342$.

Drummond, J. S., \& Themessl-Huber, M. (2007). The cyclical process of action research: The contribution of Gilles Deleuze. Action Research, 5(4), 430-448.

Educause. (2012). 7 things you should know about flipped classrooms. Educause. Retrieved from https://library.educause.edu/resources/2012/2/7-things-you-should-know-about-flippedclassrooms 
Efron, S. E., \& Ravid, R. (2013). Action research in education: A practical guide. New York, NY: The Guildford Press.

Enfield, J. (2013). Looking at the impact of the flipped classroom model of instruction on undergraduate multimedia students in CSUN. TechTrend, 57(6), 14-27.

Fullan, M. (2013). The new pedagogy: Students and teachers as learning partners. LEARNing Landscapes, 6(2), 23-29.

Fullan, M. (2014). Stratosphere: Integrating technology, pedagogy, and change knowledge. Toronto, ON: Pearson.

Fultan, K. (2014). Flipping the classroom. Principal Leadership, 15(1), 50-55.

Gardner, H. (2008). Five minds for the future. Boston, MA: Harvard Business Press.

Gross, D., Pietri, E. S., Anderson, G., Moyano-Camihort, K., \& Graham, M. J. (2015). Increased preclass preparation underlies student outcome improvement in the flipped classroom. CBE-Life Sciences Education, 14(4), 1-8. doi:10.1187/cbe.15-02-0040

Herreid, C. F., \& Schiller, N. A. (2013). Case studies and the flipped classroom. Journal of College and Science Teaching, 42(5), 62-67.

Honeycutt, B. (2016). Flipping the college classroom: Practical advice from faculty. Madison, WI: Magna.

IBM. (2006, July). The toxic terabyte: How data-dumping threatens business efficiency. Retrieved from http://www935.ibm.com/services/no/cio/leverage/levinfo_wp_gts_thetoxic.pdf

Kereluik, K., Mishra, P., Fahnoe, C., \& Terry, L. (2013). What knowledge is of most worth? Teacher knowledge for 21st century learning. Journal of Digital Learning in Teacher Education, 29(4), 127-140.

Khanova, J., McLaughlin, J. E., Rhoney, D. H., Roth, M. T., \& Harris, S. (2015). Instructional design and assessment: Student perceptions of a flipped Pharmacotherapy course. American Journal of Pharmaceutical Education, 79(9), 1-8.

Kovach, J. V. (2014). Leadership in the classroom. Journal for Quality \& Participation, 37(1), $39-40$.

Laman, J. A., Brannon, M. L., \& Mena, I. B. (2012, Jun). Classroom flip in a senior-level engineering course and comparison to previous version. Paper presented at the American Society for Engineering Education (ASEE) Annual Conference, San Antonio, TX. Retrieved from http://www.asee.org/public/conferences/8/papers/4028/view

Marshall, C., \& Rossman, G. B. (2011). Designing qualitative research (5th ed.). Los Angeles, CA: Sage.

McLaughlin, J. E., Griffin, L. M., Esserman, D. A., Davidson, C. A., Glatt, D. M., Roth, M. T., ... Mumper, R. J. (2013). Pharmacy student engagement, performance, and perception in a flipped satellite classroom. American Journal of Pharmaceutical Education, 77(9), 1-8. 
Merriam, S. B. (2009). Qualitative research: A guide to design and implementation. San Francisco, CA: Jossey-Bass.

Mertler, C. (2017). Action research: Improving schools and empowering educators (5th ed.). Thousand Oaks, CA: Sage.

Miles, M. B., Huberman, A. M., \& Saldaña, J. (2014). Qualitative data analysis: A methods sourcebook (3rd ed.). Los Angeles, CA: Sage.

Mills, G. E. (2017). Action research: A guide for the teacher researcher (6th ed.). Boston, MA: Pearson.

Milman, N. (2012). The flipped classroom strategy: What is it and how can it be used? Distance Learning, 9(3), 85-87.

Milton, P. (2015). Shifting minds 3.0: Redefining the learning landscape in Canada. Retrieved from http://www.c21 canada.org/wp-content/uploads/2015/05/C21-ShiftingMinds-3.pdf

Mok, H. N. (2014). Teaching tip: The flipped classroom. Journal of Information Systems Education, 25(1), 7-11.

Nielsen, L. (2012). Five reasons I'm not flipping over the flipped classroom. Technology and Learning, 32(10), 46.

Noffke, S., \& Somekh, B. (2011). Action research. In B. Somekh \& C. Lewin (Eds.), Theory and methods in social research (2nd ed., pp. 94-101). Los Angeles, CA: Sage.

November, A. (2010). Empowering students with technology (2nd ed.). Thousand Oaks, CA: Sage.

November, A. (2012). Emerging roles within the knowledge community. In L. Schrum (Ed.). Educational technology for school leaders (pp. 59-76). Thousand Oaks, CA: Corwin.

Ortlipp, M. (2015). Keeping and using reflective journals in the qualitative research process. The Qualitative Report, 13(4), 695-705.

Partnership for 21st Century Learning. (2016). Framework for 21st century learning. Washington, DC: Author. Retrieved from http://www.p21.org/storage/documents/1._p21_framework_2-pager.pdf

Patton, M. Q. (2015). Qualitative research \& evaluation methods (4th ed.). Los Angeles, CA: Sage.

Phelps, R. (2005). The potential of reflective journals in studying complexity in action. Complicity: An International Journal of Complexity and Education, 2(1), 37-54.

Pink, D. H. (2005). A whole new mind: Moving from the information age to the conceptual age. New York, NY: Riverhead Books.

Prensky, M. (2012). Partnering: A pedagogy for new educational landscape. In L. Schrum (Ed.). Educational technology for school leaders (pp. 3-23). Thousand Oaks, CA: Corwin. 
Preston, J. P., Jakubiec, B. A. E., Jones, J., \& Earl, R. (with Christensen, R., Kemp, S., Lillo, J. N., MacKenzie, K., \& DesRoche, A.). (2015). Twitter in a Bachelor of Education course: Student experiences. LEARNing Landscape, 8(2), 301-317.

Preston, J. P., Moffatt, L., Wiebe, S., McAuley, S., Campbell, B., \& Gabriel, M. (2015). The use of technology in Prince Edward Island (Canada) high schools: Perceptions of educational leaders. Educational Management Administration \& Leadership, 43(6), 989-1005. doi:10.1177/1741143214535747

Reidsema, C., Kavanagh, L., Hadgraph, R., \& Smith, N. (Eds). (2017). The flipped classroom: Practice and practices in higher education. Singapore: Springer Nature Singapore Pte.

Rotellar, C., \& Cains, J. (2016). Research, perspectives, and recommendations on implementing the flipped classroom. American Journal of Pharmaceutical Education, 80(2), 1-10.

Savin-Baden, M., \& Major, C. H. (2013). Qualitative research: The essential guide to theory and practice. New York, NY: Routledge.

Schilling, D. R. (2013, April 19). Knowledge doubling every 12 months, soon to be every 12 hours. Retrieved from http://www.industrytap.com/knowledge-doubling-every-12months-soon-to-be-every-12-hours/3950

Talbert, R. (2017). Flipped learning: A guide for higher education faculty. Sterling, VA: Stylus.

Tang, F., Chen, C., Zhu, Y., Zuo, C., Zhong, Y., Wang, N., ... Liang, D. (2017). Comparison between flipped classroom and lecture-based classroom in ophthalmology clerkship. Medical Education Online, 22(1), 1-9. doi:10.1080/10872981.2017.1395679

Tolks, D., Schäfer, C., Raupach, T., Kruse, L., Sarikas, A., Gerhardt-Szép, S., ... Hege, I. (2016). An introduction to the inverted/flipped classroom model in education and advanced training in medicine and in the healthcare professions. GMS Journal for Medical Education, 33(3), 1-23.

Waldrop, J. B., \& Bowdon, M. A. (2016). Best practices for flipping the college classroom. New York, NY: Routledge. 